\title{
Work-related injuries sustained by emergency medical technicians and paramedics in Turkey
}

\author{
Bedia Gülen, M.D., ${ }^{1}$ Mustafa Serinken, M.D., ${ }^{2}$ Celile Hatipoğlu, M.D., ${ }^{3}$ Derya Özaşır, M.D., ${ }^{4}$ \\ Ertan Sönmez, M.D., ${ }^{1}$ Gökhan Kaya, M.D., ${ }^{5}$ Güleser Akpınar, M.D. ${ }^{6}$
}

\author{
1Department of Emergency Medicine, Bezmialem Vakıf University Faculty of Medicine, İstanbul-Turkey \\ ${ }^{2}$ Department of Emergency Medicine, Pamukkale University Faculty of Medicine, Denizli-Turkey \\ ${ }^{3}$ Department of Public Health, Rize Provincial Directorate of Public Health, Rize-Turkey \\ ${ }^{4}$ Health Directorate of İstanbul, Emergency and Disaster Medical Services, İstanbul-Turkey \\ ${ }^{5}$ Department of Emergency Medicine, Antalya Training and Research Hospital, Antalya-Turkey \\ ${ }^{6}$ Department of Emergency Medicine, Şişli Training and Research Hospital, İstanbul-Turkey
}

\section{ABSTRACT}

BACKGROUND: Evaluated in the present study were locations, descriptions, and results of work-related injuries (WRIs) sustained by emergency medical technicians (EMTs) and paramedics in Turkey's most crowded city, i̇stanbul.

METHODS: After the present study had been accepted by the urban health authority, a questionnaire was emailed to the healthcare personnel of İstanbul's 195 ambulance stations.

RESULTS: Included in the present study were the responses of 901 members of staff (660 EMTs and $24 \mathrm{I}$ paramedics), with a mean age of 29.5 \pm 6.1 (min: 18; max: 6I). The majority of participants (94.9\%) had encountered verbal abuse from the public, and $39.8 \%$ had encountered physical violence from patients' relatives. Levels of satisfaction with work in emergency medical services (EMS) was also evaluated, and 510 participants (57.6\%) were unhappy. Regarding gender, female employees were more likely to be verbally attacked $(p=0.0 \mathrm{I})$, while males were more likely to be physically attacked $(p=0.00 \mathrm{I})$. It was reported that motor vehicle accidents $($ MVAs) were the most common cause of WRIs (8I.4\%), followed by needle-stick injuries (52.2\%), ocular exposure to blood and other fluids (30.9\%), and sharp injuries (22.5\%). Only $10.5 \%(n=95)$ of WRIs were reported to authorities; $488(54.2 \%)$ of participants just attended to the practice to prevent possible WRIs.

CONCLUSION: For paramedics and EMTs, risk of WRI is obviously high. Strategies to decrease and prevent verbal and physical violence should be developed.

Keywords: Accident; ambulance; paramedic; work-related.

\section{INTRODUCTION}

Emergency medical technicians (EMTs) and paramedics take immediate care of patients who are injured or unhealthy, and ensure their transportation to or from the hospital. Time spent at work is relatively longer for these healthcare em-

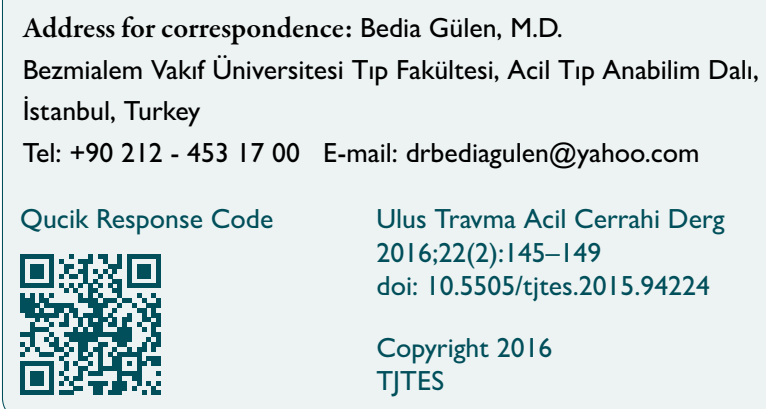

ployees, compared to those in other fields. ${ }^{[1,2]}$ Risk of injury to EMTs and paramedics is reportedly significantly higher, and the rate of work-related injuries (WRIs) has increased. ${ }^{[3]}$

Motor vehicle accidents (MVAs) play a primary role in all kinds of frequently encountered WRIs. Mortality rates have risen by $40 \%$ in Turkey, due to the increased use of ambulances (increased by $83.2 \%) .{ }^{[4]}$ Nevertheless, due to insufficient reporting of WRIs world-wide, it is now crucial that reliable information regarding WRIs sustained by EMTs and paramedics be obtained in Turkey and in other countries.

It is important to note that the most common WRIs sustained by EMTs and paramedics involve contact with bloodborne pathogens from needle sticks, injuries sustained during transportation (lifting and moving patients, etc.), wounds sustained due to patient violence, and injuries sustained as a re- 
sult of traffic accidents while on duty in ambulances. ${ }^{[5,6]}$ There are many other potential causes of WRIs, such as conflict with patients' relatives, stressful conditions, and long working hours, all of which can negatively affect personnel health.

In the present study, locations, descriptions, and results of WRIs sustained by EMTs and paramedics in Turkey's most populous city were analyzed.

\section{MATERIALS AND METHODS}

The present study was performed between March and July of 2014 in Turkey's multicultural hub, İstanbul (approximate population: 14 million). The study was approved by the Health Directorate of İstanbul. There are a total of 195 ambulance stations in the city (123 on the European side and 72 on the Asian side). These stations contain 248 emergency rescue ambulances and I40I healthcare personnel (I099 EMTs and 302 paramedics). Following the study's subsequent ac-

Table I. Characteristics of participants $(n=901)$

\begin{tabular}{|c|c|c|}
\hline & $\mathbf{n}$ & $\%$ \\
\hline \multicolumn{3}{|l|}{ Gender } \\
\hline Female & 483 & 53.6 \\
\hline \multicolumn{3}{|l|}{ Age range } \\
\hline $18-25$ & 194 & 21.5 \\
\hline $26-30$ & 408 & 45.3 \\
\hline $31-35$ & 203 & 22.5 \\
\hline $35>$ & 96 & 10.7 \\
\hline \multicolumn{3}{|l|}{ Run years in 112} \\
\hline $2-3$ years & 360 & 40.0 \\
\hline $4-5$ years & 205 & 22.7 \\
\hline 6 years and more & 336 & 37.3 \\
\hline \multicolumn{3}{|l|}{ Exposed to verbal attack ${ }^{*}$} \\
\hline By patient's relatives & 649 & 72.0 \\
\hline By society & 855 & 94.9 \\
\hline \multicolumn{3}{|l|}{ Exposed physical attack ${ }^{*}$} \\
\hline By patient's relatives & 359 & 39.8 \\
\hline By society & 166 & 18.4 \\
\hline \multicolumn{3}{|l|}{ Reported by staff? } \\
\hline Yes & 249 & 27.6 \\
\hline \multicolumn{3}{|c|}{ Institute inquired after attack? } \\
\hline Yes & 137 & 15.2 \\
\hline \multicolumn{3}{|l|}{ Pleased to work in 112 ? } \\
\hline Very well & 51 & 5.7 \\
\hline Well & 331 & 36.7 \\
\hline Not well & 362 & 40.2 \\
\hline Not very well & 157 & 17.4 \\
\hline
\end{tabular}

*Rate of attack during past 2 years. ceptance by the urban health authority, a questionnaire was emailed to all emergency healthcare personnel, who were instructed to fully complete it.

Participants were strongly advised not to enter any personal information, and were informed that collected data would be used only for scientific analysis. EMTs and paramedics with less than I year of experience who declined to participate were exempted.

The questionnaire included 23 multiple choice questions regarding frequently encountered scenarios during which WRIs may be sustained in the field of emergency medical services (EMS).

\section{Statistical Analysis}

All data were analyzed using SPSS software (version 17.0; SPSS Inc., Chicago, IL, USA). Numerical variables are presented as median and interquartile ratio, while categorical variables are presented as frequencies ( $n$ ) and percentages. Group comparisons were performed for numeric variables using the Kruskal-Wallis test, and the chi-square test was used for categorical variables. Post-hoc analysis was performed using the Mann-Whitney $U$ test with Bonferroni correction. All hypotheses were two-tailed, and an alpha critical value of 0.05 was considered significant.

\section{RESULTS}

A total of I40I EMS personnel were identified, of whom 984

Table 2. Frequency of WRI as reported by EMTs and paramedics during the past two years

\begin{tabular}{|c|c|c|c|}
\hline Mechanism & Number of injuries & $\mathbf{n}$ & $\%$ \\
\hline \multirow[t]{4}{*}{ Motor vehicle accidents } & None & 168 & 18.6 \\
\hline & 1 & 655 & 72.7 \\
\hline & 2 & 58 & 6.5 \\
\hline & $>2$ & 20 & 2.2 \\
\hline \multicolumn{4}{|l|}{ Needlestick } \\
\hline & None & 431 & 47.8 \\
\hline & 1 & 389 & 43.2 \\
\hline & 2 & 54 & 6.0 \\
\hline & $>2$ & 27 & 3.0 \\
\hline Eye contact with blood & None & 623 & 69.1 \\
\hline \multirow[t]{3}{*}{ and other bodily fluids } & 1 & 201 & 22.3 \\
\hline & 2 & 59 & 6.6 \\
\hline & $>2$ & 18 & 2.0 \\
\hline \multirow[t]{4}{*}{ Sharp injuries } & None & 698 & 77.5 \\
\hline & I & 168 & 18.6 \\
\hline & 2 & 25 & 2.8 \\
\hline & $>2$ & 10 & I.I \\
\hline
\end{tabular}


participated (70.2\%). A total of 83 personnel (8.4\%) who had been working in EMS for less than I year were excluded. A total of 90 I personnel (660 EMTs and 24I paramedics) with a mean age of $29.5 \pm 6.1$ ( $\min =18, \max =61)$ were included. Years spent with EMS (also known as the 112, after the EMS dialing code in Turkey) ranged from 2-3 for $40 \%$ of participants $(n=360)$. Demographic characteristics are shown in Table I.

Participants were questioned regarding incidence of verbal violence (insults, swearing, etc.), as well as physical violence. Participants were asked whether they had been to exposed to violence in either form by patients or their relatives in the past 2 years. Participants were also asked whether they had reported violent incidents to the administration. According to responses, $94.9 \%$ of participants had encountered verbal violence, and $39.8 \%$ had encountered physical violence from patients' relatives.

Participants were also asked to describe their level of satis-

Table 3. Data regarding mechanisms and results of injuries*

\begin{tabular}{lcc}
\hline & $\mathbf{n}$ & $\%$ \\
\hline $\begin{array}{l}\text { Mechanisms of MVAs } \\
\text { Ambulance collision with another vehicle }\end{array}$ & 483 & 53.6 \\
Ambulance crashed by another vehicle & 424 & 47.1 \\
Sudden break (injured inside ambulance) & 276 & 30.6 \\
Collision with other object & 140 & 15.5 \\
Derailing from road & 96 & 10.6 \\
Other & 27 & 3.0
\end{tabular}

The result of accident

$\begin{array}{lcc}\text { No injury } & 442 & 49.1 \\ \text { Only injured by myself } & 58 & 6.4 \\ \text { Injured only the one of I I } 2 \text { staff } & 168 & 18.6 \\ \text { Injured more than one of I I } 2 \text { staff } & 42 & 4.7 \\ \text { Injured someone on the other vehicle } & \text { II4 } & 12.7 \\ \text { Injured on pedestrian } & 36 & 4.0 \\ \text { Injured patient inside of the ambulance } & 28 & 3.1 \\ \text { Other } & \text { II } & 1.2\end{array}$

Mechanisms of needlestick injuries

During IV procedures 321

55.3

Recapping

Puncture by other needles

(following improper disposal of needles)

Other

Location of the personnel when the

needlestick injury occurred

Inside the cruising ambulance

Inside the stationary ambulance

On the field

I5 I

16.7

*Some subjects selected more than one choice. faction with work in the 112 , and 519 participants (57.6\%) reported that they were not satisfied (Table I). No significant difference in level of satisfaction was found between male and female employees $(p=0.359)$. In addition, no significant correlation was found between level of satisfaction and exposure to violence $(p=0.762$ and $p=0.284$, respectively). However, level of satisfaction among those exposed to physical violence was significantly lower $(\mathrm{p}=0.00 \mathrm{I}$ and 0.03 , respectively). While verbal violence was more prevalent among female employees $(p=0.01)$, physical violence was more prevalent among male employees $(p=0.001)$.

The most commonly reported causes of WRI were MVAs (81.4\%), needle-stick injuries (52.2\%), ocular contact with blood and other bodily fluids (30.9\%), and sharp injuries (i.e., injuries by sharps other than needle sticks; $22.5 \%$ ), respectively (Table 2).

A total of $81.4 \%$ of participants $(n=733)$ had been in at least I traffic accident while on duty in an ambulance; most often, the ambulance had collided with another vehicle (53.6\%). Three healthcare personnel and 7 others died as a result of these accidents. Personnel who had not been in an on-duty traffic accident were found to have higher levels of satisfaction with 112 employment $(p=0.005)$.

Needle-stick injuries frequently occurred as a result of intravenous line procedures $(55.3 \%)$ and processes conducted in the ambulance (34.7\%; Table 3). As the age of employees increased, the number of needle-stick injuries decreased $(r=-0.63, p=0.02)$. In addition, the number of needle-stick injuries decreased with augmentation of years spent in the $112(r=-0.43, p=0.01)$. Responses regarding the most common causes of WRIs are described in Table 4. Most frequently reported were injuries sustained while riding in ambulances (30.9\%). A total of $82.2 \%$ of respondents $(n=741)$ reported that were properly gloved, and $37.4 \%(n=337)$ reported that they were properly masked while routinely performing their jobs.

Table 4. Most common causes of WRI, according to respondents*

\begin{tabular}{lcc}
\hline $\begin{array}{l}\text { Feasible reason of the WRI regarding } \\
\text { the respondents }\end{array}$ & $\mathbf{n}$ & $\%$ \\
\hline Cruising ambulance & 278 & 30.9 \\
Hurrying up & 231 & 25.6 \\
Carelessness & 141 & 15.6 \\
Patient's movement & 119 & 13.2 \\
Failure in disposal of devices, needles etc. & 104 & 11.5 \\
Due to the relatives of the patient & 14 & 1.6 \\
Other & 21 & 2.3 \\
\hline
\end{tabular}

*Some subjects selected more than one choice. 
Only $10.5 \%(n=95)$ of WRIs were properly reported to authorities. In association, 488 (54.2\%) participants had reportedly attended an orientation designed to provide information regarding prevention of WRIs.

\section{DISCUSSION}

The present is among the largest studies of WRIs in EMS. Data indicates that $58 \%$ of participants were generally dissatisfied with EMS employment. The rate of verbal and physical violence against healthcare personnel is significantly high, and physical violence negatively affects levels of satisfaction. Findings indicate that exposure to both chronic and critical incident stressors increases the risk of EMS personnel developing post-traumatic stress reactions..$^{[7]}$

It has been demonstrated that EMS personnel encounter violence in the workplace world-wide, regardless of the country's development status. ${ }^{[8,9]}$ In a study conducted in Australia, the rate of attacks on paramedics was doubled, compared to the rate of attacks on police officers. ${ }^{[10]}$ Several factors contribute to patient violence toward EMS personnel; proper measures taken to prevent and reduce patient violence may decrease WRIs. ${ }^{["]}$ News portraying EMS personnel in an unfavorable light is prevalent in the Turkish me$\mathrm{dia}^{\left[{ }^{[12]}\right.}$ and there can be no doubt that this increases the rate of violence, causing health service personnel additional, unnecessary stress.

The present study demonstrated that the risk of WRIs to EMS personnel is higher than may have been expected. It was reported that $81 \%$ of participants had experienced at least I MVA, and that $52 \%$ had experienced at least I needle-stick injury in the past 2 years. Furthermore, the study demonstrated that needle-stick injuries most commonly occurred during intravenous administration while the ambulance was in motion. İstanbul has a very severe traffic problem, and arrival times of ambulances often surpass acceptable margins. This delay leads to ambulances rushing more, increasing the risk that EMS members will experience accidents and sustain WRIs. It is not surprising that only $10.5 \%$ of serious WRIs, including needle sticks, penetrating injuries, and ocular contact with fluids were reported to proper authorities. In a similar study performed in another large city in Turkey, only $12 \%$ of WRIs sustained by EMS personnel were properly reported. ${ }^{[13]}$ Unfortunately, the deficiency in WRI reporting is general.

In the present study, a total of $46 \%$ of participants had reportedly not undergone training related to WRIs, either before or after their EMS employment had begun. This is a significantly low rate. A close correlation between a safe working environment and safe work performed by EMS employees has been indicated. ${ }^{[14]}$ In Turkey, programs specifically designed to train EMS personnel in WRI prevention and reduction should be performed and regularly repeated.

\section{Limitations}

The present was a demonstrative study that included EMS personnel based in istanbul. Due to conditions specific to Istanbul and the limited scope of the survey, results may not be indicative of general conditions in Turkey. While deaths resulting from WRIs were investigated, non-fatal injuries were not. Furthermore, the survey concerned WRIs sustained in the past 2 years. Accuracy of responses was not verified by an outside source.

\section{Conclusion}

Risk of WRIs to paramedics and EMTs is obviously high. In order to decrease rates of physical and verbal violence against EMS personnel, additional planning and sanctions should be studied. In addition, organizations must ensure that a high level of morale is maintained. Most importantly, a mandatory certification course for all EMS and healthcare personnel should be conducted on an annual basis.

Conflict of interest: None declared.

\section{REFERENCES}

1. Kidak L, Sofuoğlu T, Keskinoğlu P, Olmezoğlu Z. A motivating experience for emergency medical services: the first Turkish Ambulance Rally. [Article in Turkish] Ulus Travma Acil Cerrahi Derg 2009;15:584-90.

2. Wood K, Crouch R, Rowland E, Pope C. Clinical handovers between prehospital and hospital staff: literature review. Emerg Med J 2015;32:57781. CrossRef

3. Reichard AA, Marsh SM, Moore PH. Fatal and nonfatal injuries among emergency medical technicians and paramedics. Prehosp Emerg Care 2011;15:511-7. CrossRef

4. Maguire BJ, Smith S. Injuries and fatalities among emergency medical technicians and paramedics in the United States. Prehosp Disaster Med 2013;28:376-82. CrossRef

5. Maguire BJ, Smith S. Injuries and fatalities among emergency medical technicians and paramedics in the United States. Prehosp Disaster Med 2013;28:376-82. CrossRef

6. Raman S, Ramnarayan P. Impact of stops for road traffic accidents on the inter-hospital transport of critically ill children. Emerg Med J 2013. [Epub ahead of print]

7. Donnelly E. Work-related stress and posttraumatic stress in emergency medical services. Prehosp Emerg Care 2012;16:76-85. CrossRef

8. Bigham BL, Jensen JL, Tavares W, Drennan IR, Saleem H, Dainty KN, et al. Paramedic self-reported exposure to violence in the emergency medical services (EMS) workplace: a mixed-methods cross-sectional survey. Prehosp Emerg Care 2014;18:489-94. CrossRef

9. Rahmani A, Hassankhani H, Mills J, Dadashzadeh A. Exposure of Iranian emergency medical technicians to workplace violence: a cross-sectional analysis. Emerg Med Australas 2012;24:105-10. CrossRef

10. Maguire BJ, O’Meara PF, Brightwell RF, O’Neill BJ, Fitzgerald GJ. Occupational injury risk among Australian paramedics: an analysis of national data. Med J Aust 2014;200:477-80. CrossRef

11. Cheney PR, Gossett L, Fullerton-Gleason L, Weiss SJ, Ernst AA, Sklar D. Relationship of restraint use, patient injury, and assaults on EMS personnel. Prehosp Emerg Care 2006;10:207-12. CrossRef 
12. Acar YA, Çevik E, Uyguner C, Cinar O. 'Emergency Service' from Press Media Perspective: Content Analysis of the News About Emergency Service in the National Newspapers of Turkey.J Emerg Med 2013;13:166-70.

13. Yilmaz A, Dal O, Yaylacı S, Uyank E. Rate of Exposure to Violence in
112 Staff in Denizli City. Eurasian J Emerg Med 2015;14:103-6. CrossRef

14. Eliseo LJ, Murray KA, White LF, Dyer S, Mitchell PA, Fernandez WG. EMS providers' perceptions of safety climate and adherence to safe work practices. Prehosp Emerg Care 2012;16:53-8. CrossRef

\section{ORIJINAL ÇALIŞMA - ÖZET}

\section{Türkiye'de acil tıp teknisyenleri ve paramediklerin karşılaştıkları iş kazaları \\ Dr. Bedia Gülen, ${ }^{1}$ Dr. Mustafa Serinken, ${ }^{2}$ Dr. Celile Hatipoğlu, ${ }^{3}$ Dr. Derya Özaşır, ${ }^{4}$ Dr. Ertan Sönmez, ${ }^{1}$ Dr. Gökhan Kaya, ${ }^{5}$ Dr. Güleser Akpınar ${ }^{6}$}

1Bezmialem Vakıf Üniversitesi Tıp Fakültesi, Acil Tıp Anabilim Dalı, İstanbu
2Pamukkale Üniversitesi Tıp Fakültesi, Acil Tıp Anabilim Dalı, Denizli
${ }^{3}$ Rize İ Sağlık Müdürlüğü, Halk Sağlığı Departmanı, Rize
${ }^{4}$ İstanbul İ Sağlık Müdürlüğ, Acil ve Afet Yönetimi, İstanbul
${ }^{5}$ Antalya Eğitim ve Araştırma Hastanesi, Acil Tıp Anabilim Dalı, Antalya
${ }^{6}$ Şişli Etfal Eğitim ve Araştırma Hastanesi, Acil Tıp Anabilim Dalı, İstanbul

AMAÇ: Bu çalışmada, Türkiye'nin en kalabalık şehri olan İstanbul'da acil tıp teknisyenleri ve paramediklerin işle ilişkili yaralanmaları tanımlandı. GEREÇ VE YÖNTEM: İstanbul'da toplam 195 ambulans istasyonu mevcuttur. Çalışma İstanbul İ Sağlık Müdürlüğü tarafından onaylandı. Çalışma anketi II 2 sağlık çalışanlarının e-posta adreslerine gönderildi ve doldurulması istendi.

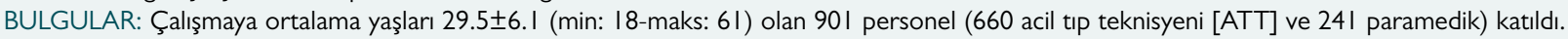
Çalışanların halk tarafından sözel şiddete uğrama oranı \%94.9, hasta yakınları tarafından fiziksel şiddet oranı \%39.8 olarak belirlendi. Bunun yanında çalışanların II2'de çalışmaktan memnun olup olmadığı araştırıldı. Beş yüz on (\%57.6) katılımcı memnun değildi. Cinsiyete göre kadın katılımcılar sözel şiddete $(p=0.0 \mathrm{I})$, fakat erkek katılımcılar da fiziksel şiddete kadınlardan daha fazla maruz kalmıştı $(p=0.0 \mathrm{I})$. İş ilişkili yaralanmaların en çoğu motorlu araç kazaları (\%8।.4), iğne batma yaralanmaları (\%52.2), kan veya vücut sıvıları ile göz teması (\%30.9) ve keskin alet yaranmaları (\%22.5) idi. İş ilişkili yaralanmaların \% I0.5’i ( $n=95)$ örneğin iğne batma yaralanmaları ve vücut sıvılarının göze teması gibi yaralanmalar yönetime rapor edilmişti ve bildirilmişti. Katılımcıların 488'i (\%54.2) olası iş ilişkili yaralanmaları önlemek için hizmet içi eğitimlere katılmıştı.

TARTIŞMA: Ülkemizde iş ilişkili yaralanmalarda ATT ve paramediklerin riski oldukça açık bir şekilde yüksektir. Bu nedenle acil çağrı sistemi personeline fiziksel-sözel şiddeti önlemek için daha ileri stratejiler geliştirilmeli ve iş kazalarına yönelik hizmet içi eğitimler artırılmalıdır.

Anahtar sözcükler: Ambulans; iş-ilişkili; kaza; paramedik.

Ulus Travma Acil Cerrahi Derg 2016;22(2):|45-I49 doi: 10.5505/tjtes.20I5.94224 